\title{
THE PRINCIPLES AND PRACTICE OF JUSTICE IN TRADITIONAL IGBO JURISPRUDENCE
}

\author{
Ikenga K. E. Oraegbunam
}

\section{Introduction}

Justice is a cardinal pillar of Igbo judicial and legal systems. The Igbo have a very strong sense of justice which is littered in many an Igbo cultural ethos and pathos. The proverbs, idioms, folklores, folk songs and other linguistic sources are some important purveyors of this value system. Igbo justice is practised in land matters, inheritance issues, socio-communal development strategies, interpersonal relationships and sundry avenues. This paper seeks to examine these sources and scenarios with a view to deciphering the fundamental concepts and principles of autochthonous Igbo justice system. It will equally inquire into whether or not the principles and practice of justice in traditional Igbo enclave are still sustainable in the light of the present wave of globalization. This study will be capped with a juxtaposition of traditional justice administration with the prevailing Nigerian justice/legal system. In other words, it will examine the status and position of indigenous system vis-à-vis English-style regime imbibed, as it were, in Nigerian jurisprudence as part of colonial legacy. Our methodology will be largely critical and analytic.

\section{Igbo Sociology and Worldview Described}

The Igbo people constitute one of the major tribal groups in Nigeria today. According to the colonial geography, the Igbo occupy mainly the eastern part of the country. They are today found in high concentration in Anambra, Abia, Enugu, Ebonyi and Imo States of Nigeria. There are also large Igbo populations in Delta and River States. Igbo people are a very migrant race. They are in large numbers resident in Northern Nigeria and in Old Ogoja, Calabari, Benin, and Lagos. More, Igbo migrants trooped out to the Cameroons, Gabon, Congo Brazzaville, Equatorial Guinea, Central African Republic, and recently to all parts of ECOWAS sub-region and the South Africa. And apart from the trans-Atlantic slave trade 
that populated Europe and the Americas with good number of Igbo elements, the $20^{\text {th }}$ and $21^{\text {st }}$ centuries have also witnessed an unprecedented influx of the people into the Western world perhaps in search of greener pastures. More so, as a result of cultural diffusion experienced both by the home front due to colonial incursion and neocolonialism and by the Diaspora who presently are in serious romance with the western culture, much of the traditional practices have undergone serious modification. This is certainly consequent upon Igbo receptivity and amenability to change. ${ }^{1}$ Hence, the Igbo traditional socio-political institutions notably communalism, "communitism", republicanism and religion have been drastically altered and modulated by imperialist incursion and Igbo access to western education, culture, Christianity and capitalism. City consciousness and urbanity have become integral components of the Igbo society. Onitsha, Aba, Enugu, Owerri, Umuahia, Awka, Nnewi, Agbor, Asaba and Abakaliki are fast growing Igbo cities populated, as it were, by hitherto rural dwellers. Another stamp of 'westernism' is made manifest in physical structures such as roads, streets, electricity, hospitals, building architecture, house furniture and home facilities, and so on.

Yet, in spite of the above foreign influence and more, certain traditional practices are quite resilient. In the hinterland, some traditional Igbo communities live in dispersed settlements. The Igbo village, which is a small face-to-face society, is still easily recognizable. A number of closely clustered compounds and families form the Igbo village, and several villages make up towns. Again, despite modern alterations, the Igbo traditional political institutions that are designed to combine popular participation with weighing for experience and ability are still in tandem with extended family sociology. The family head, the elders, the age grade, secret societies, masquerade cults, etc play a leading role in this sociopolitical structure. Economically, the Igbo in the urban areas are traders and crafts-men. In the rural areas, they are largely farmers. But in modern times, a good number are professionals in the areas of law, science, medicine, and management. The people embrace Christianity in large numbers. However, much of Igbo traditional living and attitudes is still conditioned by its traditional worldview 
which is described by Nwala as "the Igbo complex of beliefs, habits, laws, customs and tradition of reality".

In spite of the relatively new religion of Christianity, the Igbo anthropology habours a widespread belief in supreme and unique God. Chukwu (the Great Spirit), Chineke (the Creator Spirit), Osebuluuwa (the Lord who upholds the world), Ezechitoke (the Spirit King Creator), Okasiakasi (the Greatest Being), etc are some of the names with which this God is addressed. The traditional Igbo people also believe in the lesser spirits, and the ancestors through whom they can also go to Chukwu.

Igbo worldview also exudes a manifest anthropocentricism. This is the view that man occupies the central position in any meaningful human activity including religion. Writing about African worldview generally, Metuh holds that "everything seems to get its bearing and significance from the position, meaning and end of man". This is also true of the Igbo for whom in spite of the deep respect and recognition of innumerable divinities, the relevance thereof is very much subject to their effect on man. ${ }^{4}$ Hence, the Igbo have a functional, pragmatic and do ut des approach to religion and culture. Sequel to this anthropocentric sensibility is the lifeaffirming character of Igbo worldview that is often celebrated in rituals, festivals and ceremonies. The Igbo esteem life, value it, celebrate it and do anything to protect and sustain it.

Further, the traditional Igbo view reality in a noncompartmentalized manner. Their political, social, economic, cultural, moral, legal and religious aspects of life form a continuum. Everything seems to have a profound religious substractum mostly in order to enhance human life hic et nunc. It is this practical socioreligious framework that informs the traditional Igbo notion of justice.

\section{Justice Defined}

There is no generally accepted definition of justice. Etymologically, however, justice derives from the Latin "ius iustus" meaning "law", a legal right. In this sense, "law" and "justice" would be synonymous terms. But this is a misnomer. What 
is more correct is that law is to justice what a means is to an end, or a cause to an effect. Thus, apart from this etymological denotation, justice means many things and sometimes different things to many scholars for which there are myriad theories of justice. For the positivists, justice is seen as conformity to the law. For the social right theorists, justice is seen as doing what promotes the social good. But for the natural law theorists, justice is tied to the idea of natural rights where right is regarded as the ultimate basis of justice. ${ }^{5}$ Besides, different scholars and jurists have also expressed their own ideas of justice. For instance, following Aristotle, Thomas Aquinas defines justice as "firm and constant will to give each one his due". 6 Similarly, Spinoza identifies justice with the "habitual rendering to everyman his lawful due". John Rawls describes justice as "fairness". 8

Be that as it may, the concept of justice is a very rich one. Justice has been classified into moral, civil, criminal, distributive, commutative, retributive, substantial, commercial, divine, private, social, compensatory, vindictive, conservative, legal, penal justice, and so on. In what immediately follows, this study will examine the notion of justice in Igbo traditional Igbo thought forms.

\section{Principles of Justice in Traditional Igbo Mindset: Theoretical Perspectives}

In order to discover the primordial sense of justice among the traditional Igbo, it may be necessary to first and foremost, analyze the Igbo words for justice: "akankwumoto" and "ikpenkwumoto". While "akankwumoto" denotes justice as a virtue of a particular person, "ikpenkwumoto" or "ikpeziriezi" refers to the expression of this virtue in practical judgment at the event of dispute. The latter can also be described as truthfulness in making judicial decisions.

Etymologically, "akankwumoto" derives from three other Igbo words: " $a k a$ " (hand), "nkwu” (stand, remain, stay), and "oto" (straight, erect, upright, not crooked, etc). Thus, the word "akankwumoto" literally means keeping one's hand straight. It denotes uprightness of conduct. In the same vein "ikpenkwumoto" stems from "ikpe" (judgement, case, decision, verdict), " $k w u$ " 
(stand, stay, remain), and "oto" (straight, erect). Literally, "ikpenkwumoto" means judgement that is straight. The analysis of these two Igbo words shows that the Igbo concept of justice stresses the notion of physical straightness akin to the meaning of the Hebrew "sedaqa". 9 This idea of straightness in relation to justice can refer to an action or person. In the former sense, it means that one's life is straight-forward, upright, honest, predictable and impartial. In the latter understanding, a just action is one that is not crooked, is performed as it should be, is done in a disinterested manner, or has followed a due process.

But on a more profound consideration, the word "akankwumoto" derives from the context of farming on the land which was largely the main occupation of the traditional Igbo. The traditional Igbo owned land family by family. That is to say a large piece of land instead of to a private individual and sometimes to a community belonged to an extended family. It is only by way of temporary partition that each nuclear family or individual got a specific piece of land to cultivate. Even up till today, this practice of communal ownership of land is still prevalent in the hinterland. In order to divide the land among nuclear families, since the Igbo had no theodolite or official surveyors for that purpose, they normally chose young men who were of good reputation, trusted by community and known for their previous experience of keeping their hands straight while dividing the farm land. In addition to these qualities, the young men must be willing to undertake the difficulties involved in going through the equatorial scrub during the process of division in order to make sure that a straight line is maintained. Above all, they must be docile to listen to the wise counsel of the elders who intermittently advised them in these words: "Nwa $\mathrm{m}$ kwuba aka gi oto" (My son keep your hand straight), or "Emegbuna onye obula" (Do not cheat anybody). It is in this sense of straightness in dividing the farm land that "akankwumoto" came to denote the idea of justice in traditional Igbo sensibility. It is thus by extrapolation that "Ikpenkwumoto" also became an explanation for a just judgment emanating from a just and straightforward man. 
Be that as it may, Nzomiwu observes that as the history of the Igbo people progressed, the words "akankwumoto" and "ikpenkwumoto" gathered a metaphorical and a more comprehensive meaning. ${ }^{10}$ According to this development, justice becomes any action that conforms to the omenala (tradition), which constitutes the grundnorm, to use kelson's terminology. ${ }^{11}$ Justice, thus, becomes conformity with the requirements of the custom and tradition. A man who keeps the injunctions of Omenala which contains the duties of a citizen in all its ramifications is regarded as a just man. In the same vein, the word "ikpenkwumoto" became a judgement that conforms to the tradition (omenala). In other words, any judgment that is not consistent with the Omenala is not constitutional and as such null and void. Such a judgment cannot be binding on any party. It somewhat violates what the English law would call the principle of "stare decisis" and it is bound to be unjust (mmegbu) which condition aims at or attempts to deprive one of his life or entitlements.

Besides, the Igbo sense of justice is quite condensed in Igbo oral tradition. Illustrations from two of the sources of this tradition may be helpful. Thus, justice is expressed in Igbo proverbs and names. Let us take them one by one. Among the Igbo people, the use of proverbs in the communication of ideas is very invaluable. A proverb for them is a figure of speech in which many lofty ideas and philosophy are concealed and congealed. In referring to African proverbs, Herskovits regards them as constituting the "grammar of values". ${ }^{12}$ In proverbs are condensed the nitty gritties of Igbo customs, ethical standards, traditional wisdom, and wise sayings. For the Igbo, proverbs constitute the spice or salt of human communication ( $n n u$ e ji eri okwu). Certainly, the Igbo understanding of justice in all its ramifications is well expressed in various proverbs. Let us now give some instances of Igbo proverbs that explain different aspects of Igbo conception of justice.

Firstly, there is a group of proverbs that emphasize the Igbo sociological philosophy of live-and-let-live, harmony, peaceful coexistence, and consideration for the needs of others. Examples of these proverbs include "Egbe bere ugo bere nke si ibe ya ebela nku kwapu ya" (let the kite perch and let the eagle perch also, whichever 
denies the other its perching right, let its wings break off), Obiara be onye abiagbula ya, O ga-ana mkpumkpu apuna ya (The guest should not harm the host and while going home the host should see that he goes home peacefully, or literally, "may the peaceful visitor go home without a hunchback"), Okeleku amana uma taka akpa dibia ma dibia amana uma bu okelekwu onu (let the rat not eat furrows into the native doctor's bag but let the native doctor not curse the rat for mere flimsy reasons), Onye anwuna ma ibe ya efuna (let nobody die nor let his neighbour get lost), Onye ilo $m$ diri ma $m$ diri (let my enemy live and let me also live), Iwe nwanne na-ewe adighi eru n'okpukpu (the anger against a brother does not penetrate down to the bone), etc.

There is also the second group of proverbs that emphasize justice as co-responsibility within the community. Some instance can be quite illustrative: Ofu mkpulu aka luta mmanu o zue ndi ozo onu (when one finger gets soaked with palm oil, it quickly spreads to other fingers). This explains the social or corporate dimension of justice or injustice among the Igbo. Other proverbs under this group includes Aka nri kwoo aka ekpe aka ekpe akwoo aka nri (let the right hand wash the left hand and let the left hand wash the right hand, that both may be clean), Onye ji akwu toolu nchi na nchi adighi ali enu (whoever has palm nut let him drop some to grass-cutter because it does not climb). The implication is that among the Igbo, justice includes help to the needy and obligation to help the poor, the lowly and the helpless members of the society. Also among the proverbs that emphasize the value of corporation and community life in matters of common good is the one: A nyukoo mamiri onu ogboo ufufu (much foam would be made if many people urinate into a place together).

More so, some proverbs describe Igbo sense of justice as equality of opportunity, metaphysical equality of all human beings, and justice as fairness especially within the context of a community. Ya bara onye bara onye (let the advantages or opportunity be equally shared) and Isi ntutu a karo ibe ya (no individual human being is greater than the other) are examples of such proverbs. 
Furthermore, some group of proverbs stress the idea of penal and retributive justice for those who are opposed to the community goal or attempt to trample on other people's rights. Such proverbs include Isi kote ebu ebu agbagbue ya (if any body attracts the bee, the bee will sting him to death), Ochu nwa okuku nwe ada (he who pursues the cock or the hen is the one to fall), Onye si anyi adina, ya bulu okuku uzo naba ura (may he who wishes us death experience it prematurely), Onye si ala adina mma, ya doo ya n'azu (let him who glories in sowing seeds of discord in the community not live to see order and harmony restored), Okpa nsi na okpa aja, aka nsi na aka aja ba ya onu (may he taste poison who seeks to poison others or may the perpetrator of injustice and disharmony be a victim of his very action), Okuku bere na ngige, ngige egwn okuku egwu (whenever a cock perches on a rope tied to two ends, both the cock and the rope will be dancing), Oji anyi amu ije ga-agho ngworo (let him be a cripple who uses us for a walking stick), etc.

Finally, some proverbs assert the need for individual rights in spite of the community consciousness of the Igbo. E kechaa n'obi eke na mkpuke (after sharing on the basis of extended family, there will be sharing on the basis of nuclear family), Nke $m$ bu nke $m$, nke anyi bu nke anyi (my own is my own, our own is our own), Olu onye dokwa ya ndu (let one's occupation provide for one's old age), Nke onye diri ya (let each man enjoy his right), Nriko na nkeko egbunam (may I not die for living community life) are some instances of those proverbs that emphasize the respect for individual rights and entitlements.

Yet another form of Igbo orature that conveys the Igbo conception of justice is found in the various names the Igbo give to their children. Unlike in some Euro-American cultures where importance is not so much attached to names for which Shakespeare asks the question: "What's in a name"?, names are quite meaningful and symbolic in Igbo enclave. While some Europeans give such names like Kettle, Bush, Wood, Stone, and so on, to their children without much reasons therefor, the Igbo names are not just tags or mere sounds. Igbo names are not mere conventional nominalistic signs or verbal puffs but summarize one's conception of the thing so named. Personal names are thought to reveal information about the 
bearer or describe the circumstances surrounding the birth of the bearer, or even explain the experiences of the bearer's parents. Among the Igbo, to be nameless is to be worthless. The Igbo man regards his name not as a mere label, but as a distinct part of his personality. For the Igbo, to know a person fully is to know his name. More still, in Igbo worldview, names reveal sentiments, aspirations and hopes. They are the most accurate and succinct records of the Igbo people's beliefs, socio-ethical concepts and culture. Names portray the virtues the Igbo admire and the vices they detest. Above all, names sum up the features of the things to which they are attached.

In line with the above mindset, some Igbo names express the concept of justice. It goes without saying that among the people, justice is symbolized with the word Ofo. Therefore, all Igbo names that have the word ofo as a suffix or prefix have one thing or the other to refer to or demonstrate about justice. A good number of these names show the importance, necessity, effectiveness and superiority of the virtue of justice over other virtues. Ofoka (justice is greater or superior), Ofodile (justice does not kill), Ofoma (justice knows) are some examples of such Igbo names. Besides, some Igbo names express the Igbo contempt of and antipathy to certain practices or attitudes that smack of injustice. Nzomiwu ${ }^{13}$ observes two Igbo names that show scorn for unjust tendencies and thus warn the Igbo community of the danger of acting in accordance with such attitudes. The first name is Aboka which full expression is "Aboka Ife Atunye Isi" meaning that "revenge will kill or undo one". By this, a man who is vindictive is warned that if he continues with such an attitude, he will suffer for it. In other words, by that name, the Igbo emphasize that retaliation and vindictiveness is not part of their understanding of justice. Hence, the idea of justice as reconciliation and forgiveness is extolled. Secondly, the name "Ikpeamaeze" which literally means "The King is never guilty" is quite illustrative of the Igbo rejection of injustice as violation of the principle of rule of law. A part of the meaning of rule of law according to Dicey is that every citizen is under the law and that no body is above it. All are subjected to the ordinary laws of the land as interpreted by the 
ordinary courts. ${ }^{14}$ Thus, by giving the name Ikpeamaeze, the highly republican and egalitarian Igbo political anthropology far from glorying in that state of affair expresses its disapproval for it. Although some scholars have another interpretation of this name, yet the end result is coterminous with a manifest consternation with which the Igbo view any acts that breach the principle of the rule of law. For instance, Nzomiwu anchors his explanation of the meaning of the name on the so-called "Igbo-enwe-eze" slogan. According to him, most Igbo communities had neither kings nor chiefs. He argues that the existence of chiefs now in many Igbo communities is a later development due to cross-cultural contact. Thus, the name 'Ikpeamaeze' is used to scorn those communities that had kings and chiefs who naturally would never be imputed with guilt in any event. This is because being powerful, they would either by hook or crook, get justice on their sides. Hence, the name "Ikpeamaeze" expresses the Igbo disaffection and repudiation for the resultant miscarriage of justice. Nzomiwu's point of departure based, as it were, on the socalled "Igbo-enwe eze" is a highly controversial matter setting Igbo historians and anthropologists into hot debating camps but which discussion is beyond the scope of this study. However, Nzomiwu's conclusions are in tandem with Igbo disapprobation with the fact that chiefs and kings do maneuver justice. More still, the Igbo traditional religious sensibility is also replete with the Igbo conception of justice. Some theophoric names the Igbo take bear this out. Chukwuma (God knows), Chukwumanjo (God knows which is sinful or wicked), Chukwumaobi (God knows the secrets of the hearts), Chukwuobo (Revenge is God's), Chukwugboo (May God Settle), Chukwunagbako (God keeps record of all things), Chuwkunweugwo (To reward belongs to God), Chukwunagolum (God testifies to my innocence) are some instances of such names. The Igbo therefore believe in the retributive justice of God whose actions are identified with justice and equity. He is "Chuwkujiofo" (God holds justice and equity). For the Igbo, God often dispenses this justice through the deities especially Ala (Earth Goddess), Ancestral spirits, masquerades, and man. ${ }^{15}$

Even as Igbo sense of justice is also conveyed via the folklores, folksongs, rituals and mythologies, let the above 
discussions suffice for the theoretical consideration of the justice system. It may then be necessary to investigate the actual transmutation of the theory of justice into some practical matters by the traditional Igbo.

\section{Justice in Praxis among the Traditional Igbo}

There is no gainsaying the fact that the traditional Igbo theory of justice is frequently tested in a number of areas. We shall consider a few of these areas.

\section{(i) Criminal Matters}

Surely one salient means of practicing the Igbo concept of justice is criminal causes and matters. The Igbo recognize two main classes of offences: those that are "nso" and those that are not. Green refers to the former as taboos and to the latter as natural offences. ${ }^{16}$ The first group of offences is often identified as abomination (alu) which consists in acts regarded as violations against the divine laws. These range from murder, incest to theft of some highly valuable property such as yams. The second group of offences comprises the natural crimes such as other forms of stealing, failure to join in the community projects, and disobedience to other man-made laws. The Igbo retributive and penal justice is demonstrated in the punishments meted to the respective offenders which include death penalty in very extreme cases, ostracism, banishment, restitution, fine, compensation, forfeiture, seizure of valuable property, caricature and so on. But above all the Igbo criminal and penal justice systems are premised on the important value of reconciliation and peace-making. It is not necessarily based on the lex talionis approach of the hard core retributivism. There is thus an admixture of the retributive and utilitarian/ consequentialist modes that issue in the deterrent, rehabilitatory, reparatory, reformative, expiatory, educative and incapacitative objectives of penal jurisprudence. Suffused with a religio-moral and socio-cultural sensibilities, Igbo criminal justice is theandric comprising, as it were, the human and divine aspects. Sometimes, the gods are left to decide in cases that involve oath-taking and trial by ordeal. 


\section{(ii) Inheritance Issues}

Another window through which the Igbo practice justice is inheritance issues. However, in this regard, justice is more or less practised in terms of equity rather than equality. It is therefore according to this sense that the property of a man who died intestate is inherited by male children alone. If he had no male children, the inheritance goes to the brothers. Female children are not normally seen as heirs in traditional Igbo anthropology for they are regarded as transient soon to be married out of the family. Wives are also not to inherit the husband's property since they themselves are inheritable. Inheritance is therefore thought to belong to males on whom it is believed that the burden of family responsibility and upkeep lies. Even when a part of the inherited property is in the custody of the wife, for instance, the wife is taken to be a mere trustee thereof for the benefit of the male children especially. Thus, Igbo sense of justice in terms of inheritance matters is administered in accordance with the need and maturity of the heir instead of by arithmetical equality.

\section{(iii) Land Disputes}

It is not for nothing that the Igbo concept of justice is expressed in the term "akankwumoto" which is derived from the ambience of land distribution. The Igbo have their main occupation as farming and agriculture and as such have an unprecedented attachment to land. In addition to this, one's land is almost an absolutely inalienable property. Until recently, lands were a communal property which could be partitioned to individuals for settlement and farming purposes. At the event of boundary dispute or trespass, the Igbo sense of justice was brought to bear by way of traditional history and adjudicated over by the Council of Elders. In the olden days when the use of block fence was not yet made, boundaries were effected by the use of some resilient trees such as "ebenebe" and "ogirishi" which can survive the adverse effects of various weathers. In land disputes, what is therefore just is identified with the goodness of the title and correspondence with boundary. 


\section{(iv) Marital / Family Tension}

The family is an important institution in traditional Igbo sociology. It is equally the grassroot of Igbo politics. In the family, the husband and wife or wives unite to raise up children for the purpose of perpetuating the family and for its progress. Infertility is often a major cause of dispute between husband and wife. Idleness, irresponsibility, and laziness on the part of the children normally invite the dispute between husband and wife. Idleness, irresponsibility, and laziness on the part of the children normally invite the displeasure and disillusion of the father especially one who works hard to train the children. On the other hand, lack of provision of the basic utilities on the part of the head of the family who should be the breadwinner would occasion ill-feeling from the wife and the children. These are some of the causes of tension within the family. Settlement of disputes is normally through family dialogue. At the failure of this, the extended family (Umunna) and in some cases the clan and the in-laws would be invited to look into the matter. Reconciliation is usually the principal aim of such settlements since that would be the only favourable and desirable result of resolution of dispute between parties that are closely related and need each other.

\section{(v) Inter-Town Clashes}

The traditional Igbo enclave was a closed society. The concept of neighbourhood and neighbourliness was highly a restricted one. The farther the blood ties, the more distant and shallower the friendliness. The result is that there were often mutual tension and hostility between neighbouring towns. More often than not, other towns and more distant clans were regarded as actual or potential enemies to be dealt with at the slightest provocation. No doubt, the ready-to-hand causes of this face-off or fisticuff include land boundary disputes, murder of a member of a particular town, maltreatment of a town's daughter married out to another town, market quarrels, desecration of masquerades by members of another town, and so on. Resolution of this sort of conflicts took the form of negotiation and plea bargaining between the two towns. Often, 
representations from the two towns would meet to iron out the differences. In the more recent times, the representatives would be led by the respective traditional rulers and cabinets. At the end, justice is done in terms of compensation, reparation, apology, and payment of damages.

The above constitutes only a tip of an iceberg of the different fields that awaken the dispensation of Igbo sense of justice. It may however be appropriate to also note some important modes and means of settlements of disputes as employed by Igbo judicial system. We shall consider only three of these modes, namely, arbitration, oath-taking, and trial by ordeal.

\section{(a) Arbitration}

Arbitration is a recognized means of settlement of dispute among the traditional Igbo. The contention of Allot that there is nothing like arbitration practice among the Nigerian peoples does not apply to the Igbo. For Allot, what is called arbitration among the traditional Nigerian peoples is a mere negotiation for settlement in which the parties thereto are always free to resile from the arrangement any time before the award is made. ${ }^{17}$ This view of Allot received a judicial stamp in the dictum of Uwaifo J.C.A (as he then was) in the case of Okpurunwu v. Okpokam ${ }^{18}$ in which the learned judge held that "there is no concept known as customary or native arbitration in our jurisprudence".

Be that as it may, the above respective views of the legal scholar and the learned judge do not represent the correct picture of the situation. Among the Igbo, arbitration was the commonest means of dispute resolution in which the parties in lis agree to submit their dispute to the chiefs and elders of the community for the purpose of adjudication and redress, and wherein the parties feel themselves bound by the decision of the arbitrators. This practice paradoxically had also received a benediction from the Supreme Court which held in Egesimba v. Onuzurike ${ }^{19}$ thus:

Customary arbitration by elders of the community is one of many African customary modes of settling disputes and once it satisfies the necessary requirements, the decision would have binding effect 
on the parties and this creates an estoppel. It is recognized under Nigerian jurisprudence.

Even in Okpurunwu, Oguntade J.C.A (as he then was) while dissenting from the lead judgment by Uwaifo reiterated the existence of arbitration among the African natives:

I find myself unable to accept the proposition that there is no concept known as customary or native arbitration in our jurisprudence.... The right to freely choose an arbitrator to adjudicate with binding effect is not beyond our native communities....

Morestill, the Igbo customary arbitration is in tandem with the court's definition of the practice in Agu v. Ikewibe ${ }^{20}$ as that "founded on the voluntary submission of the parties to the decision of the arbitrators who are either chiefs or elders of their communities and the agreement to be bound by such decision..." Therefore, arbitration practice among the Igbo people in particular ${ }^{21}$ and Nigerian peoples generally is not unknown to Nigerian jurisprudence. Fairly recently, the Supreme Court had to reemphasize its understanding of arbitration in NNPC $v$. Lutin Investment $L t d^{22}$ wherein it is seen as "the reference of a dispute or difference between not less than two parties for determination, after hearing both sides in a judicial manner, by person or persons other than a court of competent jurisdiction". Besides, the Nigerian court's description of arbitration is not an isolationist standpoint. It is quite congruous with that of scholarly non-indigenous authors and jurists on the subject. In the words of Fulton Maxwell J,

Arbitration is a process whereby a private disinterested person called an arbitrator, chosen by the parties to a dispute..., acting in a judicial fashion but without regards to legal technicalities, applying either existing law or norms agreed by the parties, and acting in accordance with equity, good conscience and the perceived merit of the dispute makes an award to resolve the dispute. ${ }^{23}$ 
Therefore, there is no gainsaying that what arbitration stands for everywhere is well represented in the Igbo practices. Okafor ${ }^{24}$ describes the process of arbitration in traditional Igbo society. At the event of dispute the injured party may refer the matter to his kinsmen (Umnna) if the other party is also of the same kindred. Otherwise, or if it fails, the case could be reported to the village elders, age grade society, or recently the town union who serve as the arbitral panel. The panel is expected to invite the parties, fix the date and venue, and state the applicable procedure. The honouring of the invitation by the parties is a complete submission to the panel's jurisdiction and hence agreement to be bound by the resultant award. Usually, the parties are expected to say the truth and the arbitrators to stand for justice. To ensure this, the arbitral process normally begins on a ritual and religious note as observed by green ${ }^{25}$ and which can thus be summarized: The two disputants are each required to bring palm wine. Before those present would begin to drink the palm wine, the eldest man takes a cup of the wine and pours it on the four "ofo" saying to the effect that whoever is guilty, let him be guilty, and whoever is not guilty, let him not be guilty. The second eldest man takes a small chicken brought by the defendant and holding it up, pulls its head off and lets the blood drip on the "ofo" and then throws it away, saying: "whoever sees the truth in this case, and does not say it, may ofo kill him! Whoever speaks a lie, may ofo kill him! Whoever hears a word in this case and does not speak it, may ofo kill him! Whoever does not judge aright, may ofo kill him'. At the end of each statement, all those present normally respond "Ha" or "Iha" meaning "let it be so!" No doubt, the essence of the above religious ritual is to invoke and invite the supernatural to oversee and supervise the trial process. The trial itself follows the "hear-both-sides" rule of natural justice in which the plaintiff and the defendant would be heard in turn. The parties may also field in witnesses who are also heard. At the end, the panel hands on the award which is understood by the parties as binding on them. The arbitral award which normally orders restitution, compensation, apology, specific performance, etc in favour of the innocent party, if in civil matter, is binding on the guilty party failing which he is 
liable to ostracism. In criminal causes, depending on the gravity of the offence, fine, forfeiture, banishment, compensation or even death penalty may be meted out. Noteworthy is that this bindingness of traditional Igbo arbitral award inter alia distinguishes arbitration from other possible forms of dispute resolution mechanism among the people such as mediation, conciliation, reconciliation and so on. In these later forms where there is no stamp of finality, the parties are free to resile midway or at the end of the process. After all, what is envisaged is a mere negotiation for settlement.

Thus, the above discussion shows that arbitration practice among the traditional Igbo possesses the essential features of customary arbitration. First, there is an agreement between parties (though sometimes implicit) to arbitrate. We refer to it as "implicit" since often it is only at the instance of one party that refers the matter to a panel that other agrees to arbitrate once he submits to the jurisdiction of the arbitral panel. Second, there is arbitration in line with the customary law of the parties. Third, there is the existence of the award and its publication. Certainly these three factors are consistent with the Supreme Court's holdings about what the plaintiff needs to prove for the enforcement of the award. That is to say, in spite of the fact that the Supreme Court had enumerated in a number of decided cases ${ }^{26}$ different factors to be established by the plaintiff, yet the above three elements are recurrent and constitute the essential ones. But what is also salient is that all these cases emanated from the Igbo customary arbitral practice as evident from the names of the parties. This is a demonstration of the fact that dispensation of justice through arbitration is common place among the traditional Igbo.

\section{(b) Oath-Taking}

It cannot be overstated that oath-taking is an acceptable practice and a common feature of customary law resolution of dispute in Africa generally and the Igbo in particular. In spite of western influences, oath-taking has survived as a legitimate judicial method which the Igbo believe as one of the assured ways of 
obtaining absolute justice. Okogeri observes that oath-taking is an integral part of the Igbo custom by which the guilty and the innocent with regard to a dispute are exposed in view of maintenance of social equilibrium and cohesion. ${ }^{27}$ Edu, writing about the Igbo, rightly asserted that oath-taking is a common feature of resolving dispute. He notes that its use is very frequent in crime detection or as a last resort in settling other disputes such as land, adultery and defamation. ${ }^{28}$ Okafor also notes that oath-taking or swearing to a tutelary deity is usually called for in a protracted case where the intricacies of the matter make it difficult to discern who is right or wrong in a case. ${ }^{29}$ The prevalence of oath-taking among the Igbo in settlement of dispute is attested to by Oba who observes that "virtually all the reported cases on juju oaths in the country concern Igbo litigants". 30

Besides, oath-taking is a direct submission to the supernatural tribune for settlement of disputes and whose verdict is final. Man plays little or no part. Sometimes this appeal to the supernatural is made when human efforts fail or when no confidence is reposed on the human panel. This is practised in serious cases like murder, witchcraft, and in land matters. Okafor describes the procedure:

As a legitimate legal action, the injured party may ask the accused to swear on tutelary deity of his (the injured) choice to prove his innocence.... On the other hand, the accused may opt to swear on any powerful "Alusi" in order to free himself from the accusation. If the plaintiff accepts the accused's offer to swear, he is bound to regard the dispute as closed and to await for the supernatural judgement.... The perjurer may die as the result or he may suffer grave misfortune or illness. The more dreadful consequence is that the perjurer's family and sometimes, the entire village may suffer from some obscure illness which may put the lineage in danger of complete extinction. ${ }^{31}$

In the same vein, Nwakoby observes that in oath-taking among the Igbo, time is normally given within which the offending 
party is expected to either be killed by the gods or be sick so as to confirm that he is the offending party. ${ }^{32}$ Guilt or innocence is established depending on whether or not the accused dies or falls sick within the time given. Generally, the oaths are worded in such a way that the swearer invokes on himself a conditional curse. He tells the juju to punish him if he lies. After then, all the disputing parties wait for a year. The Igbo believe that anyone who swears falsely will be dead or struck with great misfortune within the time limit. In a land dispute, the person who swears to the oath enters and takes possession of the land. But if any misfortune befalls him within one year, the res will revert to the other party. If however he survives the prescribed time, the swearer retains the property as he is deemed to have told the truth. Where a party was ordered to proffer a juju for the other party to take and he fails, the other party is judged the truthful party. ${ }^{3}$

More still, the use of oaths swearing displaces the need to weigh oral evidence of the parties and their witnesses. Okany observes that given the swearing to an oath, the dispute will not normally be taken to court again, but the relatives of the diseased who is believed to have sworn falsely will surrender the disputed property or right to the other party. In some cases, the entire estate of the deceased party will be surrendered to the juju by which he swore, by way of expiation. ${ }^{34}$

\section{(c) Trial by Ordeal}

Trial by ordeal is yet another common means of settling dispute among the traditional African generally and the Igbo in particular. Talbot writing about peoples of Southern Nigeria, regards trials by ordeal among them as one of the greatest safeguards of justice". ${ }^{35}$ The Igbo practice is ad rem to the Black's Law Dictionary description of trial by ordeal:

A primitive form of trial in which an accused was subjected to a dangerous or painful physical test, the result being considered a divine revelation of the person's guilt or innocence. The participants believed 
that God would reveal a person's culpability by protecting an innocent person from the torture.... ${ }^{36}$

This view corroborates the observation of Elias in relation to Nigerian, nay, Igbo peoples as regards the various ways in which trial by ordeals can be carried out:

The ordeal might take the form of the juice of a tree (eg sass wood) mixed with water, or a burnt powder made from it and dissolved in water; a knife or other piece of iron might be heated in a fire; the culprit might be taken to a nearby pond or stream. The guilty one is he who should drink the water and become sick, handle the redhot knife and get burnt, or sink when immersed in water. ${ }^{37}$

Penwill writing about the Kamba people notes that trial by ordeals is most used in not only criminal cases but particularly in cases of theft and murder when the culprit is unknown. ${ }^{38}$ Even in fairly recent times, Igbo trial by ordeal has been applied to witchcraft cases. Also widows who were suspected of having killed their husbands were subjected to one form of trial by ordeal or the other. Sometimes, the accused was forced to drink the bath-water used in washing the corpse of the diseased. The belief is that she would die if she is guilty; otherwise her innocence would be established if unharmed. The Igbo widow faced other forms of trial by ordeal such as being locked up over night with her husband's corpse, not being allowed to touch her body with her hands as she constantly held sticks or knife in the hand, taken naked to shrine for purification, not being allowed to take her bath for 7 market days ( 28 days), forced to do early morning cries so as to wake neighbours up for at least 7 days, and so on. In line with these practices, an Igbo widow, Cecilia Akuego-Onwu recounts her recent personal experience of a trial by ordeal at the demise of her husband:

I was forced to sit near the corpse of my husband till daybreak. They (his relations) put kola nut on his chest and forced me to eat it. They made it compulsory that I must eat without washing my hands or clearing my 
teeth for seven-market days, equivalent to one calendar month. On every market day, about three o'clock in the morning, they sent an old widow to escort me with a lamp to a nearby river to take a bath. This according to them meant that if I killed my husband, he would come out of the river and avenge his death. ${ }^{39}$

Similarly, the goal of the above ordeals is that if the widow was privy to the death of the husband, then in respective cases, the dead husband would use the knive or the stick to kill the widow, or the widow would die from the eating of the kola nut, or from any of the tortures or treatments mentioned above.

Such as the above constitute the main lines along which the traditional Igbo practice justice and settle their disputes. One thing recurrent however is the fact of the religious or ritualistic underpinning in which the practices are enmeshed. Whether in arbitration, oath-taking, or trial by ordeal, the reference to the supernatural is always made. This is typically illustrated in a fictitious civil trial recorded in Achebe's Things Fall Apart. ${ }^{40}$ This was a matrimonial case between Uzowulu and Mgbafor. In this case, the Egwugwu oracles which symbolized judicial authority and power presided. The petitioner and respondent presented their cases and witnesses from both sides testified. After series of arguments and counter-arguments, the nine Egwugwu oracles went underground to consult after which they reappeared and passed their judgment. In much of Igbo justice systems, the primary motif is to effect reconciliation between disputants. This is well demonstrated in the judgement of the Egwugwu who in the instant case held that "our duty is not to blame this man or to praise that one but to settle the dispute". This is true as they commanded the petitioner to go to his in-laws with a pot of palm-wine to implore his wife to return to him, and in the same way ordered the defendants to accept such wine should the in-laws bring it and let their sister go with them. ${ }^{41}$ It should be noted that it is only when human reconciliation becomes extremely difficult or impossible that recourse is directly made to trial by ordeal or oath-taking. Sometimes however, some of the cases 
by way of latter methods are believed to be outside the jurisdiction of man. In what immediately follows, let us see the attitude and challenges posed to Igbo traditional jurisprudence by the prevailing Nigerian legal system today.

\section{Attitudes and Challenges of Nigerian Legal System to Traditional Igbo Justice System}

Surely, the relationship of the Nigerian English-style system and the tradition Igbo regime of justice dispensation is that of master and servant. Precisely as a chunk of colonial legacy, the Nigeria legal system regards the Nigerian customary laws generally as inferior and thus adopts an a la carte approach with regard to the acceptance and enforcement of traditional systems. The former picks and chooses which aspects of the latter to abolish, suppress or enforce depending on whether or not those aspects are supportive of its interests. Although Nigeria gained independence from the British rule nearly five decades ago, much of its laws and judicial methods remain largely western. In the heydays of colonialism, laws made for the colonies were styled in such a way that they either promoted the objectives of the colonial overloads or made not to injure the psycho-social sensibilities of the masters. The effect is that today, partly as a result of irresponsibity but also partly due to neo-colonial and cargo-cult mentality, the autochthonous ruling elites have maintained almost wholesale the provisions of the colonial laws for governance even up till today. ${ }^{42}$ The domino effect is that much of the colonialist antipathy to traditional customs is still retained in the Nigerian legal and judicial systems. Such retention no doubt harbours advantages and disadvantages. But a good piece of work would have been to promote the advantages and suppress the disadvantages while still adopt good foreign influences, rather than maintain a near rigid framework.

Certainly, Nigerian customary laws are saved by the Constitution of the Federal Republic of Nigerian 1999 as part of the "existing law". ${ }^{43}$ But that is only a generalized blanket provision of a legal make-belief. In actual practice, customary laws are made subject to the overriding provisions of the Nigerian English-type laws. For one thing, the whole of customary criminal justice had 
been abolished by the effects of section 36 (12) of the Constitution of the Federal Republic of Nigeria 1999. The section provides that "...a person shall not be convicted of a criminal offence unless that offence is defined and the penalty therefor prescribed in a written law..." and which written law refers to the Acts of the National Assembly or a Law of a State, any subsidiary legislation or instrument under the provisions of a law. The implication is that all unwritten crimes and all crimes not created together with their penalties by any of the aforementioned legislative authorities or belonging to any of the aforementioned groups of laws do not qualify to be part of Nigerian body of criminal laws. This means that traditional Igbo criminal jurisprudence like any other customary criminal justice one of which characteristics is that it is unwritten is constitutionally outlawed. Thus, all forms of criminal trials by ordeal, by arbitration, and by oath-taking are thereby abolished. This abolition of customary criminal justice is given an added fillip by yet another provision at section 36 (4) of the Constitution. The section requires, among other things, that "whenever any person is charged with a criminal offence, he is entitled to a fair hearing in public by a court or tribunal established by law". No doubt, this is a bar to Igbo traditional criminal courts which are neither established by law nor are their trials conducted in public. For one thing, attending the sessions and watching the proceedings are not open to all since women and children are often not allowed to participate. Because of this provision, traditional Igbo criminal trials whether by arbitration, oath-taking, or trial by ordeal which often take place in camera are rendered illegal.

Be that as it may, customary civil justice still enjoys the sympathy of the prevailing Nigerian judicial and legal systems. Hence, the courts recognize the validity of customary arbitration practice as we noted above. They also accord legitimacy to traditional methods of civil dispute resolution based on oath-taking. Although there are discordant and conflicting judicial voices with regard to oath-taking, yet long line of decided cases attracted judicial blessings on the practice especially in matters of arbitration and private dispute settlements. In Charles Ume v. Godfrey Okoronkwo 
\& Anor ${ }^{44}$ a case emanating from a native arbitration in respect of title to the land in dispute, Oguegbu J.S.C. while delivering the lead judgement stated, inter alia, that "oath-taking was one of the methods of establishing the truth of a matter and was known to customary law and accepted by both parties". Again, in Ofomata \& ors $v$. Anoka ${ }^{45}$ in which the legal validity of oath- taking was in issue, Agbakoba $\mathrm{J}$ held that

Oath-taking is a recognized and accepted form of proof existing in certain customary judicature. Oath may be sworn extra-judicial but as a mode of judicial proof, its esoteric and reverential feature, the solemnity of the choice of an oath by the disputants and imminent evil visitation to the oath breaker if he swore falsely, are the deterrent sanctions of this form of customary judicial process which commends it alike to rural and urban indigenous courts. It is therefore my view that the decision to swear an oath is not illegal although it may be obnoxious to Christian ethics....

Similarly, in the land case of Okere v. Nwoke, ${ }^{46}$ the respondent admitted the custom of settling dispute by oath-taking. Thus, the appellants having been led to take oath on the "Aka Obibi $J u j u$ " provided by the $3^{\text {rd }}$ defendant at great risk to their lives in the belief that the customary oath would settle the dispute, the respondents are estopped by conduct from denying that appellants were thereby adjudged owners of the land, the latter having sworn to the oath for over a year. Recently, the validity of oath-taking in the process of customary law arbitration was reiterated by the Supreme Court in the land dispute case of John Onyenge \& Ors $v$ Loveday Ebere \& Ors. ${ }^{47}$ The Supreme Court upheld the verdict of a lower court, which was based on the oath taken on the "Ogwugwu Akpu" of Okija in Anambra State. In this case, Niki Tobi J.S.C. delivering the lead judgment (unanimously concurred to by other Justices) reaffirmed the court's recognition of oath-taking as "a valid process under customary law arbitration". ${ }^{4}$

Curiously however, some holdings of the courts in some cases show that the courts, after all, have not spoken with one voice 
in respect of oath-taking in customary arbitration. In a long line of decided cases still, the courts denied validity to oath-taking as a means of settlement of dispute. For instance, in Iwuchukwu $v$. Anyanwu, ${ }^{49}$ Ndoma - Egba J. C. A stated:

The belief of the learned trial judge that disputes are decided by swearing "Juju" may be true as a matter of the past. In this century, that will be a retreat to trial by ordeal which is unthinkable any more than swearing 'Juju' as a method of proof. We cannot now reel back to superstitious fear and foreswear our religious faith.

Again, in Onwuanunkpa v. Onwuanunkpa, ${ }^{50}$ the court blatantly condemned practice of arbitration based on oath-taking as not being arbitration at all. More recently, the Supreme Court exhibited this attitude in Umeano Achiakpa \& Anor v. Nduka \& Ors. ${ }^{51}$ In this case, the appellants instituted an action in the High Court against the respondents claiming a declaration of title to land. The claim was founded inter alia on a judgment of the native court delivered in 1925 which was admitted in evidence as Exhibit C. The native court, however, did not order the parties to swear to the juju, but rather ordered the oath to be taken by a third party from whom the respondents traced their title. The issue before the High Court was whether or not the Exhibit $\mathrm{C}$ constituted estoppel per rem judicatam. The High Court held it did not. The Court of Appeal and the Supreme Court confirmed this. The High Court, the Court of Appeal and the Supreme Court refused to accept the native tribunal's decision to refer the case to a juju as a judicial determination of the case. The Supreme Court citing with approval the decision of the Court of Appeal held that "... a judgment which enjoins the parties to swear to a juju on to do further acts ascertained or unascertained in order to determine where the merits of the case lie is not a final judgment as it is not a pronouncement on the rights of the parties which are in dispute and it cannot operate as estoppel per rem judicatam". ${ }^{52}$ It seems that by this statement, the courts make the distinction between the situation of settlement based on oath-taking before the court is seized with the matter and that of the court 
ordering an oath-taking and depending on the result for a judicial determination of the case before it. To this extent, the courts have very strong points. However, it seems that the courts never adverted their minds to the fact that native court system was designed to be a judicial elongation and arm of the traditional political system administering substantial justice almost in the same manner as the local communities. Besides, the Supreme Court's approach is premised on the common law methodology which places more emphasis on evaluation of evidence by the judge rather than on preternatural sanctions which constitute the quintessence of traditional oaths. In our considered view, what the courts would have done is to determine whether the parties at the point of the native court's order accepted the finality of the settlement of dispute consequent upon oath-taking so as to operate as estoppel per rem judicatam. For us, the decisions of the courts in Umeano Achiakpa $v$. $N d u k a$ are tantamount to a rejection of settlement based on oathtaking.

Furthermore, some scholars have expressed their disapproval against oath-taking as a means of traditional justice administration. These opinions are well represented by Nwakoby's. The arbitration expert anchors his views on oath-taking on customary arbitration practice. He argues that since an important feature of arbitration award is finality, any arbitral award based on oath-taking is not good as the award is conditional and contingent and becomes effective only after the prescribed time in relation to the oath-taking. He also holds that there is no test of efficacy of the oath as the medical condition and state of health of the oath-taker is neither ascertained nor possibility of accident considered, and which might result to the death of the swearer even within the time prescribed. Again, for him, the entire exercise of oath-taking crumbles at the application of an antidote (ndagbu iyi) which possibility is well known to certain people. Nwakoby finally states that practice of oath-taking is not only fetish, barbaric, uncivilized, outdated, anachronistic, criminal, illegal but also contrary to Nigerian jurisprudence as it is superstitious, mysterious, and spiritualistic $^{53}$ in a society that is supposed to be dynamic and not static. 
Certainly, much of the above observations of Nwakoby is quite salient and harbours some merits. Yet it cannot be denied that even up till today in spite of western education and Christianity, many Igbo people still resort to oath-taking as a means of dispute settlement and which is given recognition by courts. As such, the practice is not outdated or anachronistic. Besides, it would not be fair to the traditional society for its practices to be judged using the parameters of western standards. Using such adjectives as barbaric, fetish or uncivilized to qualify the traditional oath-taking would not do as such is tantamount to evaluating it $a b$ extra which attitude is not acceptable in studies in cultural anthropology. The traditional people need not embrace the western culture in toto in order to be civilized or get developed. Regarding oath-taking as criminal and illegal is certainly not correct as the practice is saved and accommodated within modern Nigerian legal system as a form of statutory oath by virtue of the Oath Acts and laws. Even though the courts do not sometimes attach serious importance to oath-taking in judicial proceedings, ${ }^{54}$ yet the fact that a person may take an oath in such a manner that he considers binding on him $^{55}$ is a confirmation of statutory preservation of traditional oath-taking. In Kwara State, the Oaths and Affirmation Law provides that an oath may be offered to the other party challenging him to support his allegation by swearing to a traditional form of oath. ${ }^{56}$ Therefore, in spite of the ambivalent attitudes of the courts, both civil arbitration and justice system based on oath-taking are known and recognized by Nigerian jurisprudence. Yet as we earlier noted, the a la carte treatment meted to traditional justice system boxes it into the corner of a slave serving the interest of its master. This is made manifest in many a legal provision.

First and foremost, the traditional customary laws are relegated to the level of facts to be proved before the English-style court. In other words, even though Igbo customary laws, for instance, constitute a "mirror of accepted usage" regarded as laws which attitude is statutorily enshrined in Nigerian evidence law and practice. ${ }^{58}$ Hence, while one need not prove the other laws in courts as the judge is taken to have known them, one 
needs to establish the customary laws as he would facts by adducing evidence either by calling witnesses or by way of manuals and books $^{59}$ unless in situations where the courts had taken judicial notice of the custom. ${ }^{60}$ The implication is that the judge is regarded as not being aware of the customary laws of his own people as the proof would still be required even if the judge comes from the same customary area with the parties.

Secondly, local customs are subjected to certain validity tests through which they must pass for them to be enforced. Thus, traditional customs must not be repugnant to natural justice, equity and good conscience. They must not be incompatible to any known written law. And they must not be contrary to public policy. ${ }^{61}$ Although this judicial attitude has helped to suppress certain obnoxious practices, yet it is not without paying the price of subjecting the indigenous customs to the servitude position of kowtowing the neo-colonial legal regime operating in Nigeria today.

Therefore, it goes without saying that the Igbo customary justice system is neither here nor there. It is allowed to operate only insofar as it pays a poll tax similar to that paid by a conquered people to their conquerors for the latter to allow the former to exist. The customary system is allowed to operate provided it does not conflict with the interest and operation of the received English method that is regarded as all-too superior. The effect is that the indigenous framework is quite vulnerable and susceptible to be abolished at any time by the simplest legislative act which may not be diligent enough to carry out a proper study of the situation.

\section{Conclusion and Recommendation}

In the course of the above discussions, this paper has been able to identify the principles and practices of the Igbo sense of justice and judicial system. It is discovered that the Igbo have a very rich notion of justice which quintessence is precipitated into its reconciliatory, communal, social, and religious nature. However, this indigenous idea of justice is primordially anchored on a traditional worldview that is fast undergoing rapid transformation due to contact with western culture. This contact which is packaged in a colonial baggage gave birth to a judicial methodology that 
superimposes itself on the autochthonous system. Yet even as it is true that the Igbo of today is a hybrid, some aspects of its customs including judicial practices still die hard. The compromise stance of genuine socio-cultural symbiosis between the two judicial systems would have been the panacea. Since it is important to respond to the comprehensive judicial need of the Igbo person, it is quite apt to indigenize and inculturate the received English system. This will require a diligent study of the traditional ways in view of a proper integration with the prevailing English-style mode. There is also the urgent necessity to drop the cargo-cult mindset by which everything western is deemed the better in relation to the native counterpart. Certainly, no culture is a finished product. By means of diffusion and borrowings, each culture adjusts itself in order to still be relevant to its people. Justice systems no doubt are an important aspect of this process. Rather than maintaining the prevailing posture, the Nigerian judicial system would be better for it if the babies of the home-made and received styles are respectively saved as though in a good marriage while throwing away their bath waters. 


\section{Notes and References}

${ }^{1}$ Cf. S. Ottenberg, "Ibo Receptivity to Change" in W.R. Bascom and M. J. Herskovits (eds), Continuity and Change in African Cultures, The University of Chicago Press, Chicago, 1959, 103-104.

2 T. U. Nwala, Igbo Philosophy, Literamed Publications Nig. Ltd, Lagos, 1987, 28.

3 E. I. Metuh, African Religions in Western Conceptual Scheme, Imico Press, Jos, 1985, 109.

4 J. S. Mbiti, African Religions and Philosophy, Heinemann, London, 1977, 92.

5 Cf. O.A. Bird, The Idea of Justice, Frederick A. Praeger, New York, 1967, 10ff.

6 T. Aquinas, Summa Theologiae, IIa IIae, q. 58, a. 1.

7 B. Spinoza, A Theologico - Political Treatise, New York, 1951, 208.

${ }^{8}$ J. Rawls, A Theory of Justice, Howard Press, Cambridge, 1981.

9 J. D. Douglas, The New Bible Dictionary, Inter Versity Press, London, $1962,681$.

10 J. P. C. Nzomiwu, The Concept of Justice Among the Traditional Igbo: An Ethical Inquiry, Fides Publishers, Awka, 1999, 41.

11 Grundnorm is the key concept developed by Hans Kelson in his pure theory of law. It is the supreme norm from which all other norms receive their validity. Cf. H. Kelson, The Pure Theory of Law, Berkeley, 1967, 200218.

12 M. J. Herskovits, "Dohomean Narrative", Northwestern University African Studies, 1958, No. 1., 62.

${ }^{13}$ Nzomiwu, Op. Cit., 72.

14 A. V. Dicey, Introduction to the Study of the Law of Constitution, $10^{\text {th }}$ Edition, Macmillan, London, 1959.

15 Nzomiwu, Op. Cit., 75-99.

${ }^{16}$ M. M. Green, Ibo Village Affairs, Frederick A Praeger Publishers, New York, 1904, 99.

${ }^{17}$ A. Allot, Essays in African Law, Butterworth \& Co. Ltd, London, 1960, 126.

18 (1988)4 NWLR (pt 90) 544.

${ }^{19}$ (2002) 15 NWLR (pt 791) 466 at 512-513.

20 (1991) 3 NWLR (pt 180) 385 at 407.

${ }^{21}$ Eg. Egesimba v. Onuzuruike (supra), Agu v. Ikewibe (supra), Idika v. Erisi (1988) 2 NWLR (pt 78) 563; Njoku v. Ekeocha (1972) 2 ECSLR 199; Mbagwu v Agochukwu (1973) 3 ECSLR (pt 1) 90; Okere v. Nwoke (1991) 
\& NWLR (pt 209) 317 at 316, Ohiaeri v. Akabueze, (1992) 2 SCNJ 76 at 94; Onwu \& Ors v. Nka \& Ors (1996) 7 SCNJ, 140 at 255; Ojibah v. Ojibah (1991) 6 SCNJ 156 at 169; Igwego v. Ezeugo (1992) 7 SCNJ 284; Oparaji v. Ohanu (1999) 6 SCNJ 27; Ume v. Okoronkwo (1996) 12 SCNJ 404; Okereke v. Nwankwo (2003) 4SCNJ 211 at $221-22$; Onyenge \& Ors v. Ebere \& Ors (2004) 6 SCNJ 126 at $141-43$; Ofomata \& Ors v. Anoka \& Anor (1974) 3 ECSLR 251 at 254; Achiakpa v. Nduka (2001)7 SCNJ 585; Iwuchukwu v. Anyanwu (1993) 8NWLR (pt 311) 311 at 323; Nzeoma v. Ugocha (2001) FWLR (pt 48) 1299 at 1306; Onwununkpa v. Onwuanunkpa (1993) 8 NWLR (pt 310) 186, etc.

22 (2006) 25 NSCQR 77 at 111-112.

${ }^{23}$ Fulton Maxwell J, Commercial Alternative Dispute Resolution, The Law Book Co. Ltd, 1989, 55.

24 F. U. Okafor, Igbo Philosophy of Law, Fourth Dimension Publishers, Enugu, 1992, 70.

${ }^{25}$ Green, Op. Cit, 120 -121; Cf also Okafor, Op. Cit., $70-71$.

${ }^{26}$ In Agu v. Ikewibe (supra) and Ohiaeri v. Akabueze (supra), the Supreme Court adumbrated the following factors to be proved by the plaintiff in order to succeed in enforcing the arbitral award: (1) that the dispute between the parties was deliberated upon by a third party, (2) that the third party gave a decision in his favour, (3) that a valid customary arbitration existed where the parties voluntarily submitted to the arbitration, (4) that the parties agreed before hand to be bound by the arbitral decisions, (5) that none of the parties withdrew from the arbitration midstream, (6) that none of the parties rejected the award immediately it was made, (7) that the arbitrators reached a decision and published their award. In Egesimba $v$. Onuzuruike (supra), the Supreme Court rephrased the listing of the factors with some nuanced implications. The factors are: (1) voluntary submission of the dispute to the arbitration of the individual body, (2) agreement by the parties either expressly or by implication that the decision of the arbitrator will be accepted as binding, (3) that the arbitration was in accordance with the custom of the parties, (4) that the arbitrators reached a decision and published the award. A little further in Egesimba, the court extended the factors thus: (a) that the parties voluntarily submit their dispute to a nonjudicial body, to wit, their elders or chiefs as the case may be for determination, (b) the indication of the willingness of the parties to be bound by the decision of the judicial body or freedom to reject the decision where not satisfied; (c) that neither of the parties has resiled from the decision so pronounced. It should be noted that the factor of resiling from 
or objecting to the award as included in the list in Agu, Ohiaeri and Egesimba is quite controversial. It seems to be an assault to common sense that one is permitted by law to resile from the awards of an arbitral panel to which he initially submitted. The decision of the West African Court of Appeal in Foli v. Akese (1930) 1 WACA 1, is quite preferable. In that case, Deans $\mathrm{J}$ stated that in submission to arbitration, the general rule is that as the parties chose their arbitrator to judge in dispute between them, they cannot when the award is good on its face object to his decision either upon the law or on the facts".

${ }^{27}$ G. O. Okogeri, "Ezi Okwu Bu Ndu in Igbo Customary Law" in N. Otakpor (ed.), Ezi Okwu Bu Ndu: Truth is Life, Hope Publications, Ibadan, 2006, 174.

${ }^{28}$ O. K. Edu, "The Effect of Customary Arbitral Awards on Substantive Litigation: Setting Matters Straight”, 25 Journal of Private and Property Law, 2004, 43 at 49.

29 Okafor, Op. Cit, 72.

30 A. A. Oba, "Juju Oaths in Customary Law Arbitration and Their Legal Validity in Nigerian Courts", Journal of African Law 52, I, 2008, 139, footnote no. 4.

${ }^{31}$ Okafor, Op. Cit, 72.

32 G. C. Nwakoby, The Law and Practice of Commercial Arbitration in Nigeria, Iyke Ventures Production, Enugu, 2004, 87.

${ }^{33}$ Ume v. Okoronkwo, (supra).

34 M. C. Okany, The Role of Customary Courts in Nigeria, Fourth Dimension Publishers, Enugu, 1984, 174, n. 44.

${ }^{35}$ P. A. Talbot, The Peoples of Southern Nigeria III, Oxford Univ. Press, London, 1926, 620.

${ }^{36}$ B. A. Garner (ed.), Black's Law Dictionary, $7^{\text {th }}$ Ed., West Group, St. Paul, Minnesota, 1999, 1123.

${ }^{37}$ T. O. Elias, The Nature of African Law, Manchester Univ. Press, U.S.A., 1962, 229.

${ }^{38}$ D. J. Penwill, Kamba Customary Law, Macmillan, London 1951, 67.

${ }^{39}$ Cf www.oneword.org/tips2/jan99/1340041.htm.

${ }^{40}$ C. Achebe, Things Fall Apart, Heinemann, London, 1958, 62-66.

${ }^{41}$ Ibid.

42 The Present Nigerian Criminal Code was enacted in 1916. The Evidence Act was enacted in 1943 and took effect in 1945.

${ }^{43}$ The Constitution of the Federal Republic of Nigeria 1999, section 315.

${ }^{44}$ Supra.

${ }^{45}$ Supra. 
${ }^{46}$ Supra.

${ }^{47}$ Supra.

${ }^{48}$ Ibid.

${ }^{49}$ Supra.

${ }^{50}$ Supra.

${ }^{51}$ Supra.

${ }^{52}$ Ibid.

${ }^{53}$ G. C. Nwakoby, "Customary Law Arbitration Practice: Validity of Arbitral Award Based on Oath Taking", Unpublished Lecture to LL.M. Students, UNIZIK, Awka, 2007.

${ }^{54}$ Section 4, Oaths Law of Anambra State, Revised Laws of Anambra State of Nigeria, 1991.

55 Ibid. Section 8.

${ }^{56}$ Sections 7 and 8, Oaths and Affirmation Law, Cap 108, Laws of Kwara State 1994.

${ }^{57}$ Owonyin v. Omotosho (1961) 1 All N.L.R. 304 at 309.

${ }^{58}$ Section 14 (1) of the Evidence Act, Cap E. 14, Laws of Fed. of Nigeria 2004.

${ }^{59} \mathrm{Ibid}$, sections 14 (3) and 59.

${ }^{60}$ Ibid, Section 14 (2).

${ }^{61}$ For detailed study of the validity tests, cf Eleko v. Officer Administering the Government of Nigeria (1931) A. C. 662 at 673; Lewis v. Bankole (1908) I N.L.R. 81 at 99 -102; Dawodu v. Danmole (1958) 3 F. S. C. 46; Edet v. Essien (1932) II N.L.R 47; Re Adedevoh(1951) 13 W.A.C.A. 304 at 310; Adesubokan v. Yinusa (1971) N.N.L.R. 77., Muojekwu v. Muojekwu (1997) 5 NWLR (pt 512) 208; Alake v. Pratt (1955) 15 WACA 20; Cole v. Akinyele (1960 5 F.S.S. 84, etc. 